\title{
HABIT AND ECOLOGY OF THE PETRIELLALES, AN UNUSUAL GROUP OF SEED PLANTS FROM THE TRIASSIC OF GONDWANA
}

\author{
Benjamin Bomfleur, ${ }^{1, * \prime}+$ Anne-Laure Decombeix, $\neq$ Andrew B. Schwendemann,§ Ignacio H. Escapa, $\|$ \\ Edith L. Taylor, $†$ Thomas N. Taylor, + and Stephen McLoughlin*
}

\begin{abstract}
*Department of Palaeobiology, Swedish Museum of Natural History, PO Box 50007, SE-104 05 Stockholm, Sweden; tDepartment of Ecology and Evolutionary Biology and Biodiversity Institute, University of Kansas, Haworth Hall, 1200 Sunnyside Avenue, Lawrence, Kansas 66045,

USA; fUniversité Montpellier 2 and Centre National de la Recherche Scientifique, Unité Mixte de Recherche Botanique et Bioinformatique de I'Architecture des Plantes, Montpellier F-34000, France; §Department of Biology, Lander University, 320 Stanley Avenue, Greenwood, South Carolina 29649, USA; ॥Consejo Nacional de Investigaciones Científicas y Técnicas-Museo Paleontológico Egidio Feruglio, Trelew, Chubut 9100, Argentina
\end{abstract}

Editor: Michael T. Dunn

\begin{abstract}
Premise of research. Well-preserved Triassic plant fossils from Antarctica yield insights into the physiology of plant growth under the seasonal light regimes of warm polar forests, a type of ecosystem without any modern analogue. Among the many well-known Triassic plants from Antarctica is the enigmatic Petriellaea triangulata, a dispersed seedpod structure that is considered a possible homologue of the angiosperm carpel. However, the morphology and physiology of the plants that produced these seedpods have so far remained largely elusive.
\end{abstract}

Methodology. Here, we describe petriellalean stems and leaves in compression and anatomical preservation that enable a detailed interpretation of the physiology and ecology of these plants.

Pivotal results. Our results indicate that the Petriellales were diminutive, evergreen, shade-adapted perennial shrubs that colonized the understory of the deciduous forest biome of polar Gondwana. This life form is very unlike that of any other known seed-plant group of that time. By contrast, it fits remarkably well into the "dark and disturbed" niche that some authors considered to have sheltered the rise of the flowering plants some 100 Myr later.

Conclusions. The hitherto enigmatic Petriellales are now among the most comprehensively reconstructed groups of extinct seed plants and emerge as promising candidates for elucidating the mysterious origin of the angiosperms.

Keywords: Petriellales, gymnosperms, Triassic, paleoecology, polar forests, Antarctica.

\section{Introduction}

Since plant life conquered land in the early Paleozoic, global climates have been generally much warmer than today, enabling the terrestrial vegetation to spread far into polar latitudes (Seward 1914; Spicer and Chapman 1990; Taylor and Taylor 1990; Cantrill and Poole 2012). In the Triassic greenhouse world, lush temperate forests covered large parts of the high-latitude regions of the Gondwanan supercontinent (Taylor and Taylor 1990; Escapa et al. 2011; Cantrill and Poole 2012). Sedimentary successions of an extensive fluvial drainage system that transected this polar forest biome are

${ }^{1}$ Author for correspondence; e-mail: benjamin.bomfleur@nrm.se.

Manuscript received April 2014; revised manuscript received July 2014; electronically published October 28, 2014. today exposed in the Transantarctic Mountains; these successions have yielded abundant compression-fossil assemblages as well as silicified peat deposits that contain plant remains in exquisite anatomical detail. The rich and wellpreserved plant-fossil record from the Triassic of Antarctica provides insights into the physiology of plant growth under the strongly seasonal light regimes of a warm polar forest biome- a type of ecosystem without any modern analogue (Taylor and Taylor 1990; Escapa et al. 2011; Cantrill and Poole 2012).

Among the numerous and, in many cases, well-studied Triassic plants from Antarctica are the Petriellales-an order of enigmatic seed plants that was established with the description of a peculiar type of dispersed seedpod structure in the famous silicified peat deposit from Fremouw Peak, East Antarctica (Taylor and Taylor 1987; Taylor et al. 1994). Anatomical details led some authors to consider Petriellaea triangulata a possible homologue of the angiosperm carpel 
(see Frohlich 2003; Frohlich and Chase 2007; Doyle 2008). Compression fossils of similar cupulate structures (Kannaskoppia) and of associated pollen organs (Kannaskoppianthus) were later found in organic connection to small stems with attached leaves in Triassic deposits from South Africa (Anderson and Anderson 2003) and Australia (Holmes and Anderson 2005). The leaves (Rochipteris, Kannaskoppifolia) are apetiolate, arise helically, and have a wedge-shaped, spreading, variably dissected lamina and distinctive anastomosing venation (Anderson and Anderson 2003; Barone-Nugent et al. 2003; Holmes and Anderson 2005). Anderson and Anderson (2003, p. 288) reconstructed the South African fossils as the remains of small, erect plants that they tentatively interpreted as herbaceous pioneering shrublets or climbers (Anderson and Anderson 2003, p. 294).

Here, we present the first discoveries of petriellalean compression fossils from Antarctica. Information about the distinctive morphology of petriellalean stems and leaves enabled us to identify the corresponding anatomically preserved parts of these plants in the silicified peat deposit. Detailed analysis of morphological, anatomical, and taphonomic features of these new Antarctic fossils reveals that the Petriellales had indeed established a habit and life strategy that are unique among all known seed-plant groups of the time and much more reminiscent of early angiosperms.

\section{Material and Methods}

In the Paleobotanical Collections of the Department of Ecology and Evolutionary History and Biodiversity Institute at the University of Kansas, Lawrence (KUPB), petriellalean fossils occur in three plant-fossil assemblages from different sites in the Transantarctic Mountains (fig. 1). More or less complete remains of more than 20 leaves plus abundant leaf fragments occur on 10 hand specimens (KUPB T-234, 256, 257, 577, $581,584,585,634,661,663)$ in a compression assemblage from plant level 2 (in E. L. Taylor et al. 1990; Boucher et al. 1995; AH08 of Gabites 1985) near the base of member C of the Lashly Formation, exposed at the Feather Bay section in the northeastern arm of the Allan Hills, southern Victoria Land (fig. 1). Palynological data indicate a Carnian (early Late Triassic) age for this deposit (Kyle 1977). The second plantcompression assemblage, containing isolated leaf fragments on 11 hand specimens (KUPB T-1010, 1130, 1250, 1262, 1273, $1311,1315,1424,1429 ; 5632,5635)$, is the level 2 assemblage from a section of the upper Fremouw or the lower Falla Formation exposed on an unnamed ridge near Schroeder Hill in the Cumulus Hills in the Shackleton Glacier area; the locality is informally referred to as Alfie's Elbow (Taylor et al. 1998). In the KUPB collection, specimens collected during the 1996 field season are labeled with "level 1 base" or "level 1b," whereas those collected during the 2003 field season are labeled "level 2," according to the revised and published stratigraphic column (Taylor et al. 1998; Axsmith et al. 2000). A preliminary palynological analysis (sample AE-12 of Askin and Cully 1998) also indicates a Carnian age for these deposits.

Anatomically preserved petriellalean stems, leaves, cupulate organs, and seeds occur in several blocks (including KUPB specimens 10,023 [holotype material of Petriellaea triangulata], 10,852 [paratype material of $P$. triangulata], 17,082, and $\mathrm{CB} 545$ ) of the famous permineralized peat deposit from the uppermost Fremouw Formation exposed at a col on the north side of Fremouw Peak in the Beardmore Glacier area of the central Transantarctic Mountains (fig. 1). The exact age of this deposit remains uncertain. Following a palynological analysis by Farabee et al. (1990), the permineralized peat deposit has conventionally been assigned to the Anisian (early Middle Triassic). This dating was based on the assumption that the occurrence of Aratrisporites parvispinosus and an undetermined species of Protohaploxypinus (i.e., Protohaploxypinus cf. microcorpus) in a palynological sample from the permineralized peat would indicate an age no younger than Anisian (early Middle Triassic). However, A. parvispinosus and Protohaploxypinus species also occur in younger deposits (e.g., Helby et al. 1987). By contrast, other palynological studies (Fasola 1974; Kyle and Schopf 1982) place the uppermost part of the Fremouw Formation, which includes the silicified peat deposits, into subzone $\mathrm{C}$ of the informal Alisporites zone (Kyle 1977), indicating a late Ladinian (latest Middle Triassic) or possibly Carnian (early Late Triassic) age. We consider this latter assignment to be more likely.

All material is housed in the Paleobotanical Collections of the University of Kansas in Lawrence. Permineralized peat blocks were prepared, analyzed, and photographed following standard paleobotanical procedures (see, e.g., Galtier and Phillips 1999).

\section{Systematic Description}

Order-Petriellales Taylor et al. 1994

Family-Petriellaceae Taylor et al. 1994

Genus-Rochipteris Herbst et al. 2001, emend. nov.

Type species. Rochipteris lacerata (Arber) Herbst et al. 2001.

Synonym. Kannaskoppifolia Anderson et Anderson 2003.

Emended diagnosis. Apetiolate leaves, obovate to wedgeshaped in outline; distal margin entire, undulate, or variably incising to deeply dividing the leaf into narrow, wedge-shaped to linear segments; lateral margins entire; venation spreading from base, without midvein, generally subparallel to leaf or segment margins, with acute-angled dichotomies and anastomoses forming a loose network of elongate, rhombic to polygonal areoles.

Remarks. The original diagnosis of Rochipteris is restricted to isolated leaves only and further contained the statement "Fructifications unknown" (Herbst et al. 2001, pp. 261-262). Approximately at the same time that Rochipteris was erected, however, Anderson and Anderson (2003) introduced the name Kannaskoppifolia for essentially similar leaves that were found attached to stems (Anderson and Anderson 2003); the authors added a brief comment during the final preparation of their monograph, indicating that Kannaskoppifolia should likely be considered a junior synonym of Rochipteris (Anderson and Anderson 2003, p. 294). Holmes and Anderson (2005) later proposed to use the name Kannaskoppifolia for attached leaves and Rochipteris for isolated 

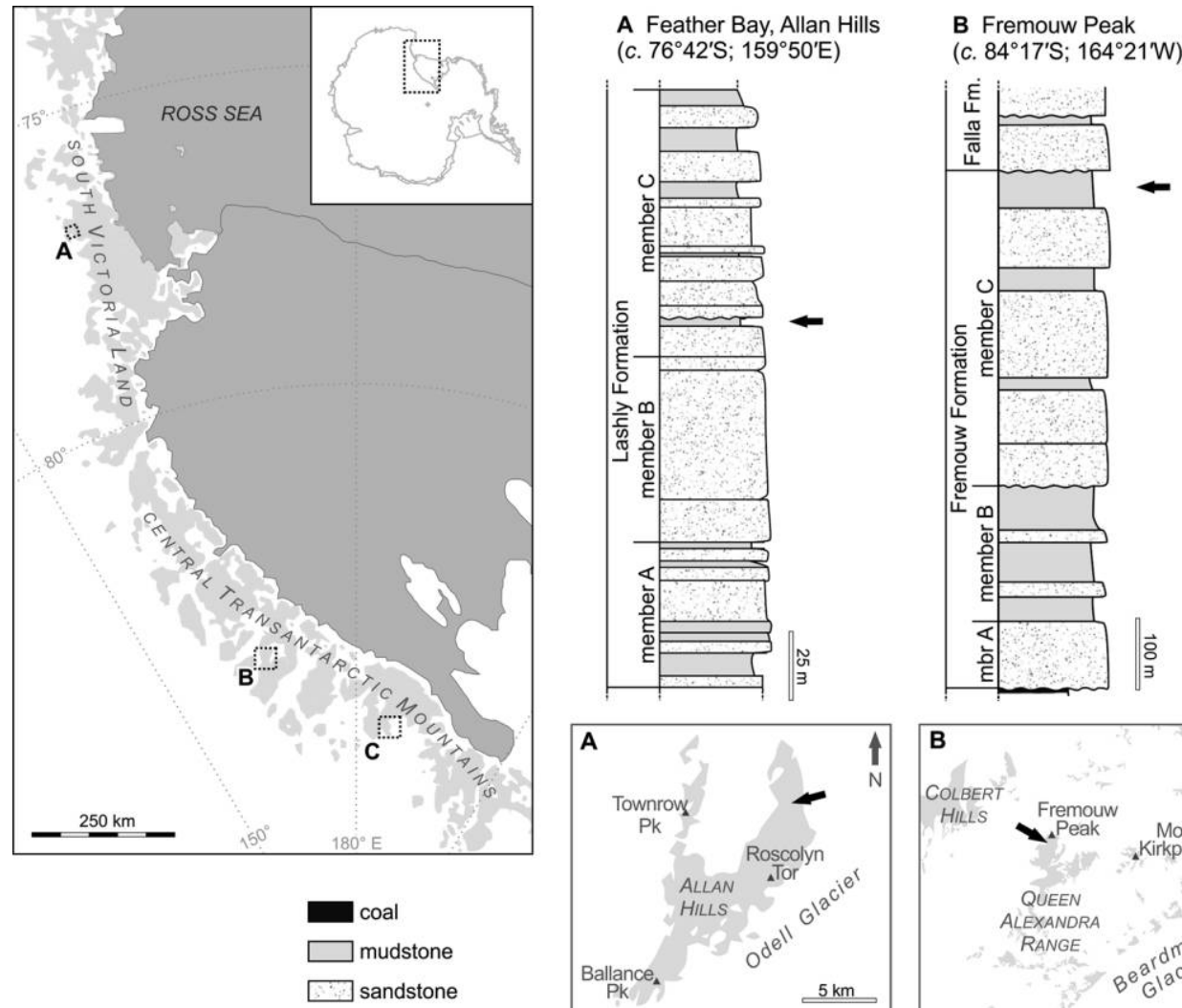

C 'Alfie's Elbow'

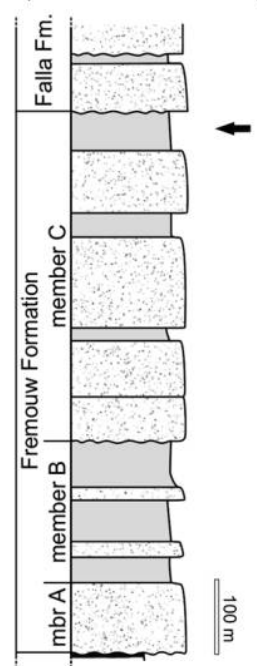

c. $\left.84^{\circ} 22^{\prime} \mathrm{S} ; 164^{\circ} 55^{\prime} \mathrm{W}\right)$
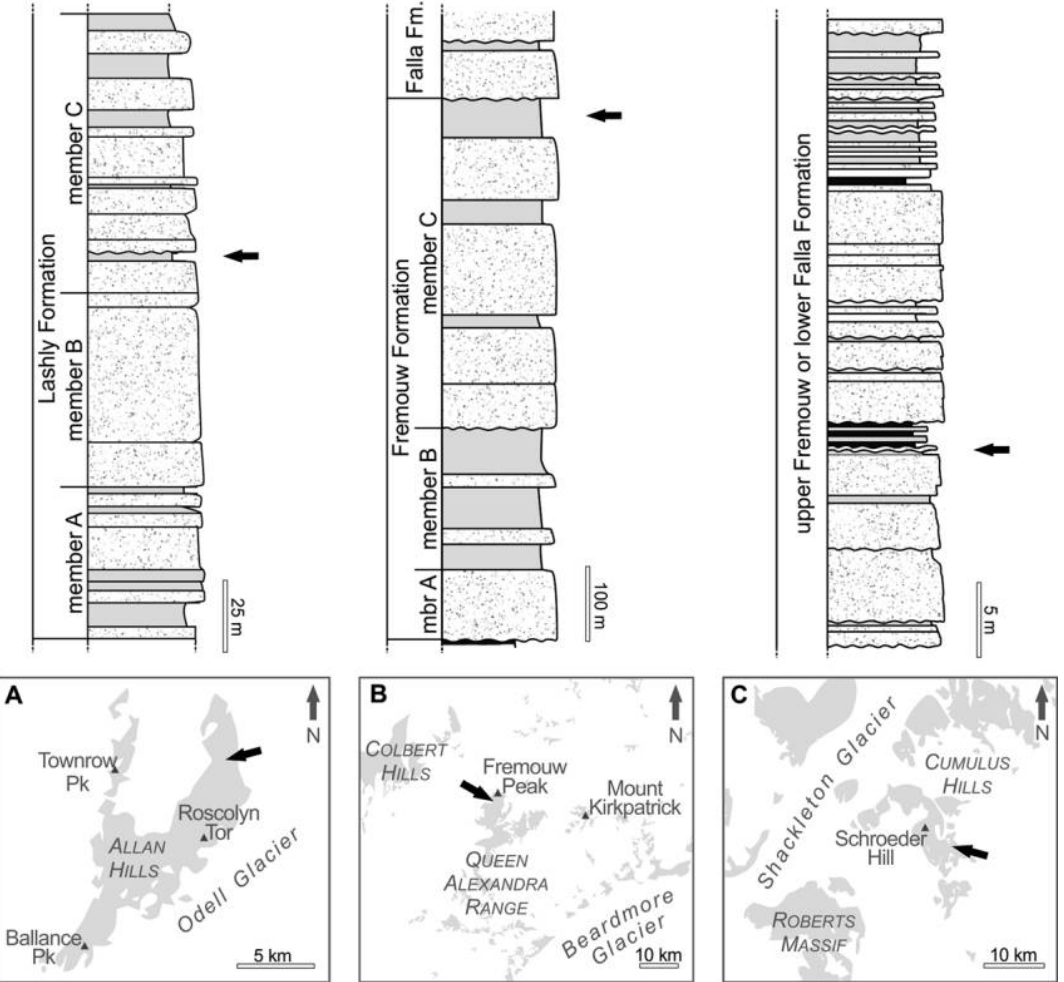

Fig. 1 Geographic and stratigraphic occurrences of the fossils. A, Feather Bay, Allan Hills. B, Fremouw Peak. $C$, Alfie's Elbow. A and $C$ modified from Bomfleur et al. (2014a); B modified from Taylor et al. (1998).

leaves. This practice would make it necessary to assign different genus names to the attached and detached leaves of the single individual plant from Allan Hills (fig. 2A). We thus object to this proposal, consider Kannaskoppifolia a junior synonym of Rochipteris, and modify the emended diagnosis to allow inclusion of attached leaves also. Furthermore, in light of the strong similarities between compressed and structurally preserved organs, we propose treating the family name Kannaskoppiaceae Anderson et Anderson (originally based on compression fossils) as a junior synonym of the family Petriellaceae (Taylor et al. 1994).

\section{Species-Rochipteris alexandriana Herbst et al. 2001}

Description. The most complete compression specimen consists of a 6 -cm-long, up to 1.5 -mm-wide, slender, curving stem that is divided into smooth, $\sim 10-15$-mm-long internodal regions and $\sim 5-10$-mm-long nodal regions with loose clusters of helically arranged leaves (fig. $2 A$ ), each arising at an acute angle from a short ( 1-mm-long), apically inclined, coneshaped, cushion-like protrusion of the cortex (fig. 2B, 2C). Individual leaves are apetiolate, wedge-shaped, up to $8 \mathrm{~cm}$ long, and up to $3 \mathrm{~cm}$ wide; they are basally divided into three main segments by two closely spaced dichotomies at a distance of $\sim 15 \mathrm{~mm}$ from the base, each segment being further dissected by $2-3$ successive acute-angled dichotomies (figs. $2 A-2 C, 3 A$, $3 B)$; the resulting lamina segments are only $0.5-2 \mathrm{~mm}$ wide, linear to narrowly wedge shaped, with entire, slightly recurved margins (i.e., adaxially convex surface; fig. $3 A$ ). The apices of ultimate segments are truncate. The venation is fine, spreading, generally straight and parallel to lamina margins, and dichotomizing sporadically at acute angles when approaching lamina dichotomies (fig. $2 B$ ). Characteristic reticulate patterns occur sparsely in distal leaf portions; these consist of a group of either a single or two parallel vein dichotomies ( $\gamma$ forms), followed by a $\lambda$-type or $\chi$-type anastomosis (see Melville 1976; fig. 3A-C). The vein number per lamina segment ranges from up to six in basal leaf portions to two or one in ultimate segments. The abaxial epidermal surface bears sparse dome-shaped protrusions of $\sim 50-150 \mu \mathrm{m}$ in diameter (fig. 3C). Additional specimens from Allan Hills consist of isolated leaf fragments; some of these have conspicuously recurved margins, similar to petriellalean leaves from South Africa (Anderson and Anderson 2003) and Australia (Holmes and Anderson 2005).

Remarks. The specimens correspond very well with the diagnosis of $R$. alexandriana from the Triassic of Chile (Herbst et al. 2001).

\section{Species-Rochipteris sp. cf. R. lacerata (Arber) Herbst et al. 2001}

Description. The material consists of up to 4-cm-long and $1.5-\mathrm{cm}$-wide fragments of spreading, presumably wedge- 

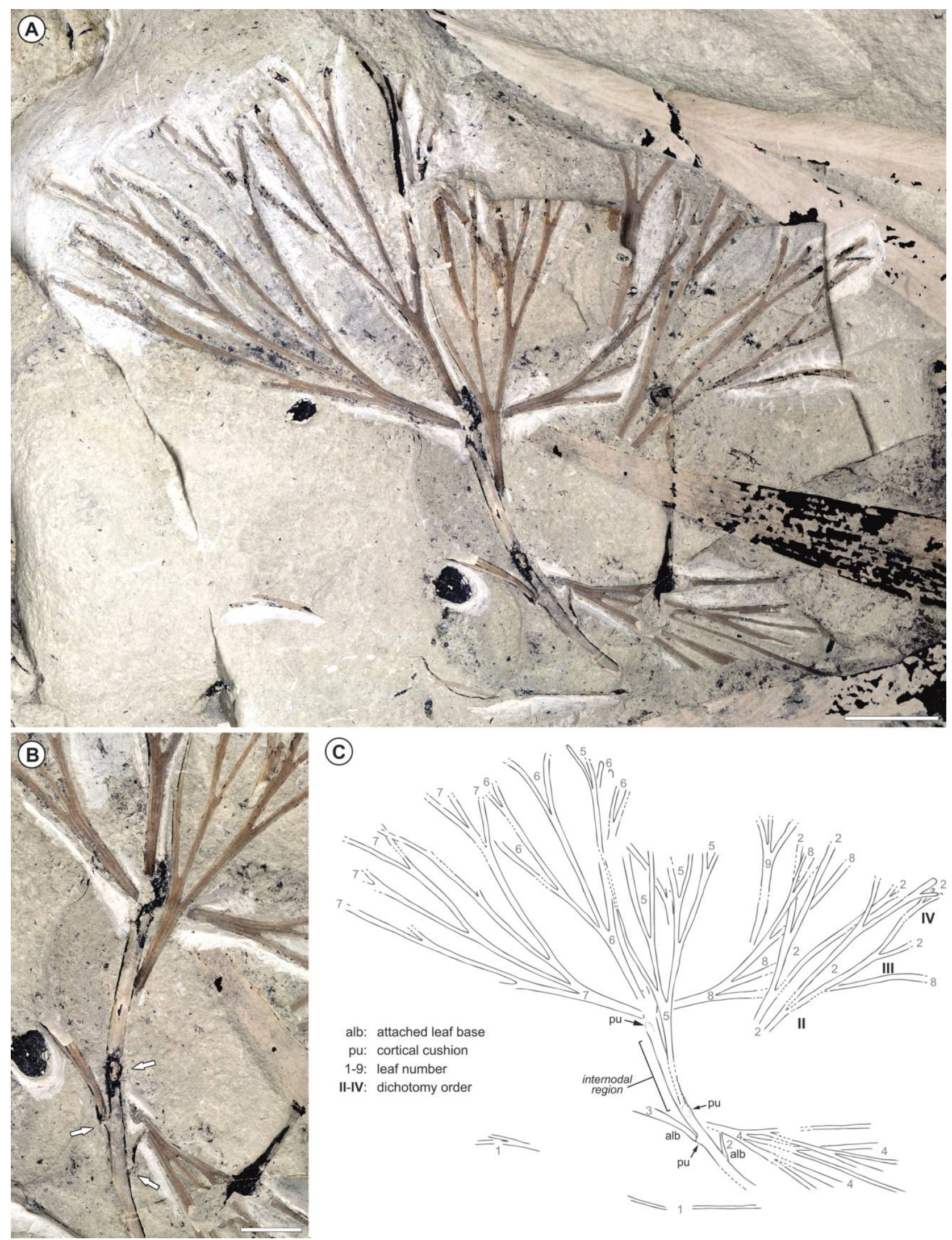

Fig. 2 Petriellalean stem with attached Rochipteris alexandriana leaves from the Upper Triassic part of the Fremouw Formation at Allan Hills, south Victoria Land, Antarctica; KUPB specimen T11-661. A, Overview of the specimen. B, Detail showing cortical cushions (arrows). C, Drawing of specimen with attached leaves illustrated on $A$. Scale bars $=1 \mathrm{~cm}$ in $A ; 5 \mathrm{~mm}$ in $B$. 


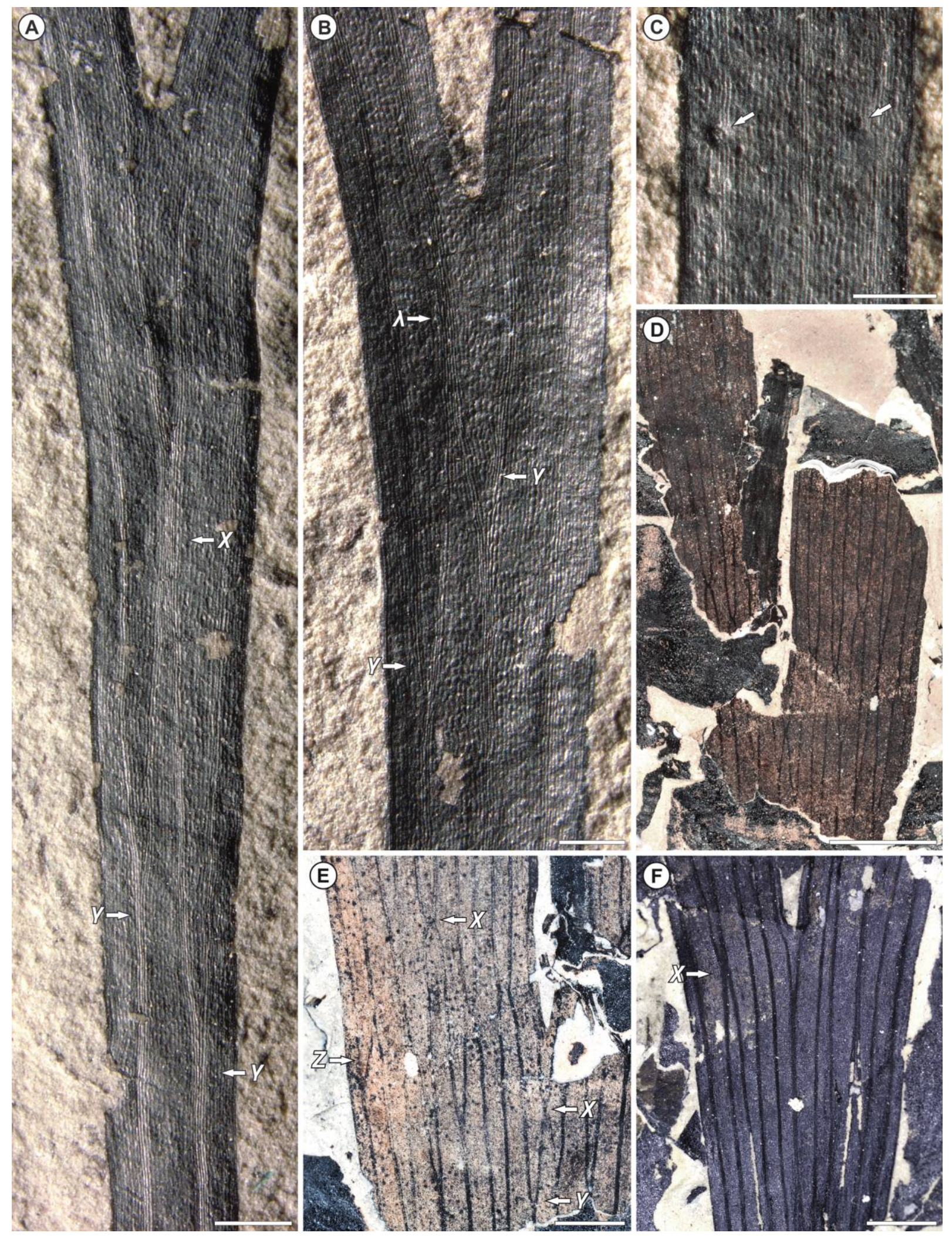

Fig. 3 Petriellalean compression fossils from the Triassic of Antarctica. A-C, Details of Rochipteris alexandriana leaves from the Upper Triassic of the Allan Hills showing two vein dichotomies ( $\gamma$ forms) followed by a $\chi$-type anastomosis $(A)$, two vein dichotomies $(\gamma$ forms) followed by a $\lambda$-type anastomosis $(B)$, and dome-shaped protrusions on the epidermal surface $(C)$. All details from KUPB specimen T11-661b. $D-F$, Fragments of Rochipteris sp. cf. R. lacerata from the Falla Formation of the central Transantarctic Mountains, showing abundant epidermal glands and characteristic anastomosing venation, including $\chi$-type and $\zeta$-type anastomoses; $D$, T1424; E, T1273; F, T1262. Scale bars $=$ $500 \mu \mathrm{m}$ in $A, C ; 250 \mu \mathrm{m}$ in $B ; 5 \mathrm{~mm}$ in $D ; 2 \mathrm{~mm}$ in $E, F$. 
shaped leaves, incised to varying depths up to at least two times (fig. 3E, 3F). Veins are fine, spreading more or less parallel to the leaf or segment margins, and have acute-angled dichotomies $(\gamma$ forms), common $\chi$-type anastomoses, and sparse $\zeta$-type anastomoses (fig. 3D-3F); the vein density is 15-20 per $10 \mathrm{~mm}$. The lamina appears membranous (i.e., conspicuously brownish and lighter-colored than other cooccurring gymnosperm foliage fossils), and intercostal fields bear densely distributed dark spots $\sim 100-200 \mu \mathrm{m}$ in diameter (fig. 3E).

Remarks. In leaf dimensions, degree of leaf dissection, and venation details, the specimens are most similar to the type species $R$. lacerata (see Herbst et al. 2001). Due to the rather strong fragmentation of the material, however, we refrain from attempting a formal identification.

\section{Genus-Rudixylon gen. nov.}

Generic diagnosis. Stems small, perennial, cylindrical, eustelic, pycnoxylic; pith large, parenchymatous; primary xylem with helical to scalariform wall thickenings, not arranged in distinct sympodia; secondary xylem cylinder with uniseriate rays. Leaves helically arranged; leaf trace with a single, wide, flattened, adaxially concave vascular bundle passing through a prominent cortical cushion.

Etymology. The genus name refers to the small size and slender habit of the stems (lat. rüdis $=$ small stick; gr. $x y l o n=$ wood).

\section{Type Species-Rudixylon serbetianum sp. nov.}

Diagnosis. Stems small, up to $\sim 3 \mathrm{~mm}$ in diameter, perennial, erect, cylindrical, eustelic, pycnoxylic; pith large in relation to entire stem diameter, up to $\sim 1.5 \mathrm{~mm}$ in diameter, parenchymatous, overall homogeneous, in some cases containing cuboidal storage cells distributed at regular vertical intervals; secondary xylem cylinder with uniseriate, parenchymatous rays up to at least 25 cells high; radial pitting of secondary xylem tracheids, with one or two rows of circularbordered pits. Leaves helically arranged, persistent. Adventitious roots containing a thin aerenchyma cylinder.

Holotype (hic designatus). Stem with attached leaf base, cross-sectioned on master peel $\mathrm{C}_{\text {top }}$, and prepared on slides $\mathrm{C}_{\text {top }} \# 01-03$ of peat-block specimen 10,852, housed in the Paleobotanical Collections of the Department of Ecology and Evolutionary History and Biodiversity Institute at the University of Kansas, Lawrence.

Etymology. The specific epithet is chosen in honor of Rudolph "Rudy" Serbet, collections manager at the University of Kansas Paleobotanical Collections, who first recognized and prepared many of the structurally preserved plants described from the Antarctic silicified peat deposits over the past decade.

Type locality. Unnamed col on the north side of Fremouw Peak, Beardmore Glacier area, central Transantarctic Mountains.

Type stratum. Blocks of silicified peat in the uppermost part of member C of the Fremouw Formation, Beacon Supergroup.

Age. Middle or early Late Triassic.
Description. Stems and leaves occur in great abundance together with isolated cupules and seeds in certain peat blocks, including those that contain the type material of Petriellaea triangulata). Stems are diminutive and measure only $1-3 \mathrm{~mm}$ in diameter (fig. 4); they have a $\sim 0.5-1.5$-mm-wide parenchymatous pith (fig. $4 A, 4 B, 4 F, 4 J$ ) and a small amount of pycnoxylic secondary xylem with up to at least four more or less conspicuous growth rings (fig. 4A, 4F). Stems with preserved bark tissues show a thin parenchymatous cortex (fig. 4C, 4J). Secondary phloem consists of a few poorly preserved cell layers. The pith parenchyma is overall homogeneous but contains small, cuboidal cells with dark contents that occur at regular vertical intervals (fig. $4 D$ ). The primary xylem does not form distinct sympodia (fig. $4 B, 4 J$ ). Primary xylem tracheids have spiral to scalariform wall thickenings. The secondary xylem consists of tracheids and parenchymatous rays that are uniseriate and up to at least 25 cells in height (fig. 4E). Radial pitting of the tracheid walls consists of one or two rows of circular bordered pits (fig. 4G). Leaf vascular traces arise steeply in the form of a single, flattened, crescentic xylem bundle that passes through a prominent cortical cushion and extends into the leaf base (fig. $4 J$ ).

Basal leaf cross sections are crescentic and contain a single, flattened, adaxially concave dorsiventral xylem bundle essentially similar to the leaf traces in the cortical cushions of the foliated stem portions (fig. $4 K$ ). A series of sections through a basal leaf portion show that this bundle then flattens and becomes dissected several times to form an even set of more or less parallel leaf veins (fig. $4 M$ ). In addition, we found one basal portion of a leaf segment in which a pair of veins forms a $\chi$-type anastomosis (fig. 5). Distal leaf portions are extremely thin, some being only four cell layers high and less than $150 \mu \mathrm{m}$ thick (fig. $4 \mathrm{~N}$ ); their mesophyll is loosely arranged, contains large intercellular air spaces, and lacks palisade parenchyma. In all leaf portions, the lower epidermis bears prominent glands that produce raised, dome-shaped storage bodies $\sim 50-100 \mu \mathrm{m}$ in diameter (fig. $4 L$ ).

Comparison and remarks. In addition to the distinctive vascularization and anatomy of affiliated leaves, the anatomically preserved stems of the Petriellales can be readily distinguished from those of the two co-occurring gymnosperm stem taxa with pycnoxylic wood, i.e., the corystosperm Kykloxylon and the conifer Notophytum. The most distinctive characters for petriellalean stems are (1) the absence of the lacunae and sclerotic nests that are present in the pith and cortex of all Kykloxylon axes, including shoot apices (Meyer-Berthaud et al. 1993) and (2) the lack of the distinctive primary xylem sympodia seen in Notophytum (Meyer-Berthaud and Taylor 1991). In addition, even 4-yrold petriellalean stems have an exceptionally small diameter of less than $3 \mathrm{~mm}$, whereas the smallest stems known for Notophytum and Kykloxylon (i.e., apices of 1-yr-old shoots) measure 5 and $4 \mathrm{~mm}$ in diameter, respectively (Meyer-Berthaud and Taylor 1991; Meyer-Berthaud et al. 1993). In those young shoots of Kykloxylon and Notophytum, leaf traces are crowded, with a very short internode, and several leaf traces can be observed on a single transverse section (MeyerBerthaud and Taylor 1991; Meyer-Berthaud et al. 1993). This is not the case in the petriellalean stems, which have a higher internode length. 

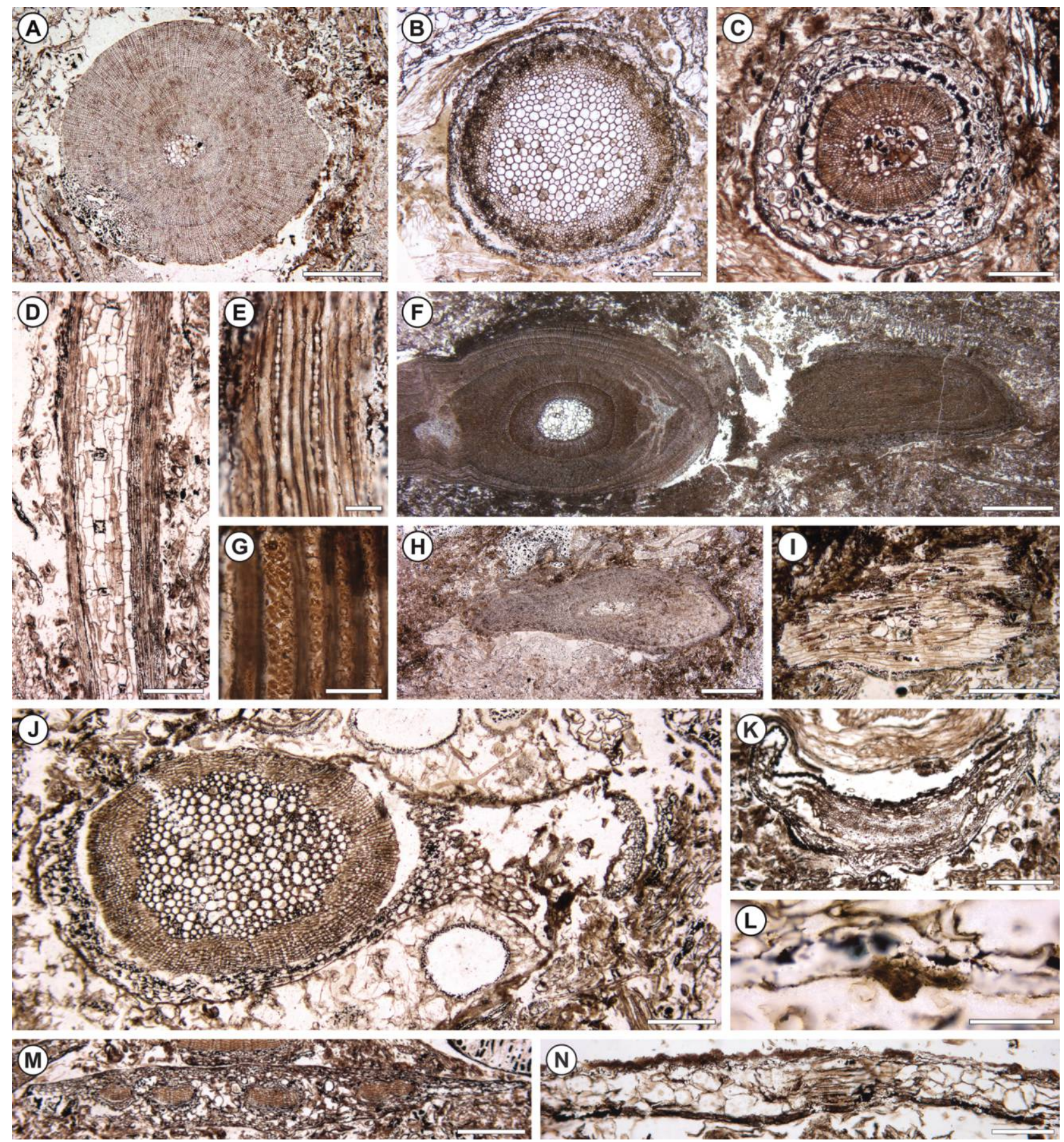

Fig. 4 Anatomically preserved petriellalean stems (Rudixylon serbetianum, gen. et sp. nov.) and leaves from Triassic permineralized peat from Antarctica. A, Cross section through large stem showing prominent parenchymatous pith and three indistinct growth rings; KUPB slide 17,082 $\mathrm{C}_{\text {top }} \# 30$. B, Cross section through young stem with particularly large pith; KUPB slide CB545A (B1-d). C, Cross section of small branch with well-preserved cortex; KUPB slide $17,082 \mathrm{D}_{\text {top }} \# 20 . D$, Radial section through stem showing cuboidal storage cells in pith parenchyma; KUPB slide 19,392. E, Detail of tangential section through stem showing high, uniseriate rays; KUPB slide 19,342. F, Cross section through a large stem with multiple branching; KUPB peel 17,082 $\mathrm{A}_{\text {top. }}$. , Detail of radial section through stem showing one or two rows of circularbordered pits; KUPB slide 17,082 $\mathrm{A}_{\text {side }} \# 4$. H, I, Stem cross section showing emerging adventitious root with aerenchyma cylinder; KUPB peel $17,082 \mathrm{D}_{\text {bot }} \# 1(H)$ and KUPB slide 17,082 $\mathrm{D}_{\text {bot }} \# 26(I)$. J, Holotype specimen showing stem cross section just below a leaf base, with prominent cortical cushion containing crescentic leaf-trace bundle; KUPB 10,852 $\mathrm{C}_{\text {top }} \# 02 . K$, Cross section through adaxially concave basal leaf portion containing crescentic dorsiventral bundle similar to the leaf-trace bundle of the holotype specimen (see A); KUPB slide 10,023 A\#109. L, Detail of leaf cross section showing gland in lower epidermis; KUPB slide 10,023 A $\approx \# 14$. M, Leaf cross section showing evenly distributed veins; KUPB slide 10,023 A\#77. N, Cross section through thin distal leaf portion; KUPB slide 19,351. Scale bars $=500 \mu \mathrm{m}$ in $A ; 250 \mu \mathrm{m}$ in $B-D, I-K, M$; $25 \mu \mathrm{m}$ in $E, G ; 1 \mathrm{~mm}$ in $F, H ; 50 \mu \mathrm{m}$ in $L ; 100 \mu \mathrm{m}$ in $N$. 

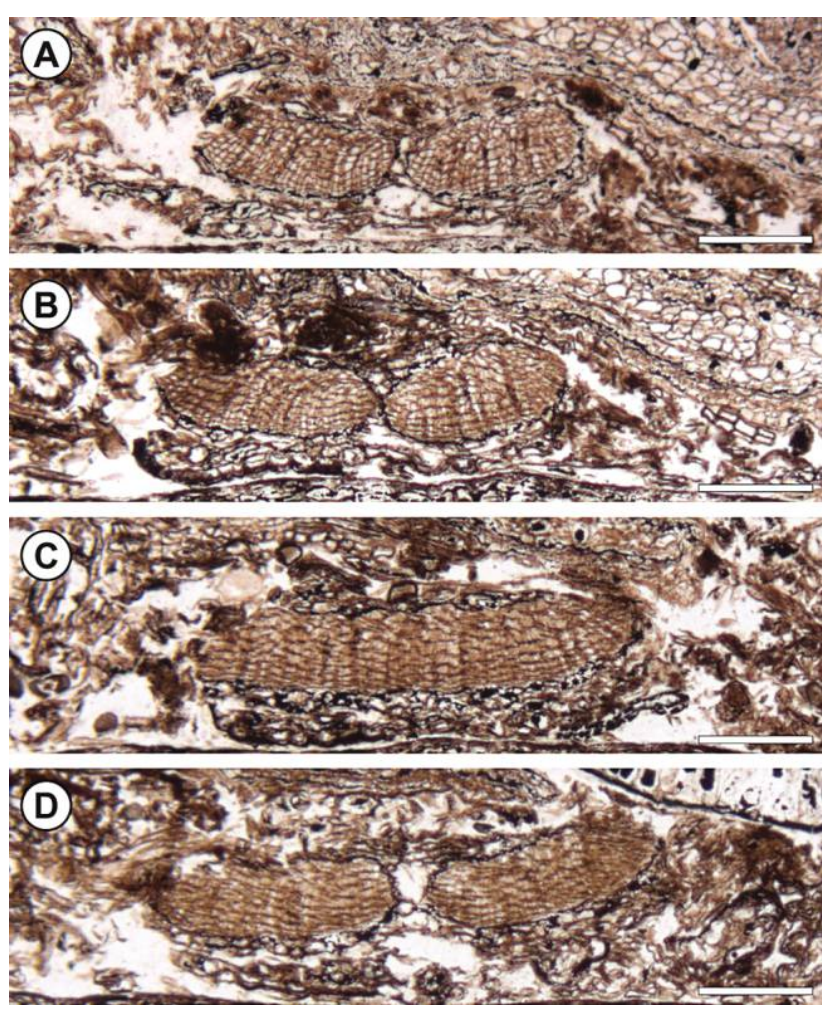

Fig. 5 Successive cross sections through a basal portion of a permineralized petriellalean leaf segment showing $\chi$-type anastomosis of vascular bundles (in C); KUPB slides 10,023 A\#119 (A), 10,023 A\#109 (B), 10,023 A\#077 (C), and 10,023 A\#58 (D). Scale bars = $200 \mu \mathrm{m}$.

A critical character in the diagnoses is the small size of the stems. It might be argued that all petriellalean fossils found so far represent young individuals of tall, arborescent plants similar to other gymnosperm taxa and that upright-buried fossils are saplings. However, this can be ruled out for the following reasons: first, given the amount of material available, one would expect to find larger petriellalean stems as well, especially given that the plants apparently grew within the depositional environment; second, one would then expect to also find young plants of other local arborescent taxa (e.g., the much more common Dicroidium and Telemachus trees), which is not the case; and finally, petriellalean fossils are commonly found together with copious amounts of either male or female reproductive organs from presumably the same individuals (see, e.g., Anderson and Anderson 2003), indicating that the fossils represent mature plants.

\section{Discussion}

The morphology, anatomy, and taphonomic context of the new Antarctic petriellalean fossils provide comprehensive information on the physiology and ecology of these peculiar plants that inhabited the middle to high latitudes of the Gondwana supercontinent (fig. 6).

\section{Habit Reconstruction}

The stems are consistently diminutive ( $<3 \mathrm{~mm}$ thick; fig. 4 ); based on stem diameter-to-height relationships among extant woody plants (Niklas 1993), the Antarctic petriellalean plants must have been less than a meter tall. Yet, the largest stems contain up to four growth rings (fig. $4 A, 4 F$ ), demonstrating that they were perennial and persisted over several growth seasons. Upright (orthotropic) growth of the axes is reflected in the combination of apetiolate, steeply inclined, simple foliage being radially arranged around the stem.

The anatomy of petriellalean foliage shows classic features of shade-adapted leaves with low photosynthetic capacities, including (1) an extremely thin lamina, (2) undifferentiated mesophyll (i.e., lacking a palisade layer), and (3) large intercellular air spaces (see Givnish 1988; Smith et al. 1997). Compared to co-occurring foliage taxa, these features are much more similar to those of understory osmundaceous ferns (see Rothwell et al. 2002) than to those of canopyforming gymnosperms, i.e., Corystospermales (Dicroidium) and voltzialean conifers (Notophytum). The latter two leaf types are considerably thicker and contain differentiated mesophyll with a palisade layer and a more or less densely packed spongy layer (Pigg 1990; Axsmith et al. 1998). The lower epidermis of petriellalean leaves also bears abundant glands that produce raised, dome-shaped storage bodies (figs. 3E, $4 L$ ). This leaf character is usually interpreted to enhance leaf durability (see, e.g., Feild and Arens 2007) and is notably absent in the deciduous foliage of the co-occurring arborescent gymnosperm taxa mentioned above (Pigg 1990; Axsmith et al. 1998; Bomfleur and Kerp 2010). Furthermore, cross sections show that the margins of petriellalean leaves attenuate into winglike extensions (fig. 4M) and are commonly enrolled or folded; similarly, many leaf compression fossils have incurved margins or appear shriveled (see, e.g., Holmes and Anderson 2005, figs. 21b, 22, 27b). We suggest that this may reflect that the Petriellales were able to acclimate to unfavorable conditions by temporarily enrolling and shriveling the leaf laminae. Altogether, this complement of features indicates a long leaf life span (see Smith et al. 1997; Givnish 2002; Feild and Arens 2007) and-in consequence-an evergreen phenology (Givnish 2002). This is supported by the growth-ring anatomy, which is characterized by a much more gradual transition from large-celled early wood to small-celled late wood than seen in the co-occurring wood of deciduous trees (Taylor and Taylor 1993; Taylor and Ryberg 2007). Further evidence for diminutive growth and evergreen habit comes from unusual taphonomic features of the petriellalean compression fossils we studied (table 1). Remarkably, petriellalean foliage seems to be commonly preserved in organic connection to stems not only in the KUPB Antarctic collections (fig. 2A) but also in other assemblages from South Africa (Anderson and Anderson 2003) and Australia (Holmes and Anderson 2005). This kind of preservation is exceedingly rare or unknown in all of the co-occurring gymnosperm foliage types (table 1). In addition, we found that detached petriellalean foliage in the Antarctic collections is always strongly fragmented and have never observed complete and isolated leaves, which, by contrast, is the common mode of leaf preservation of the co-occurring gymnosperms (Bomfleur 


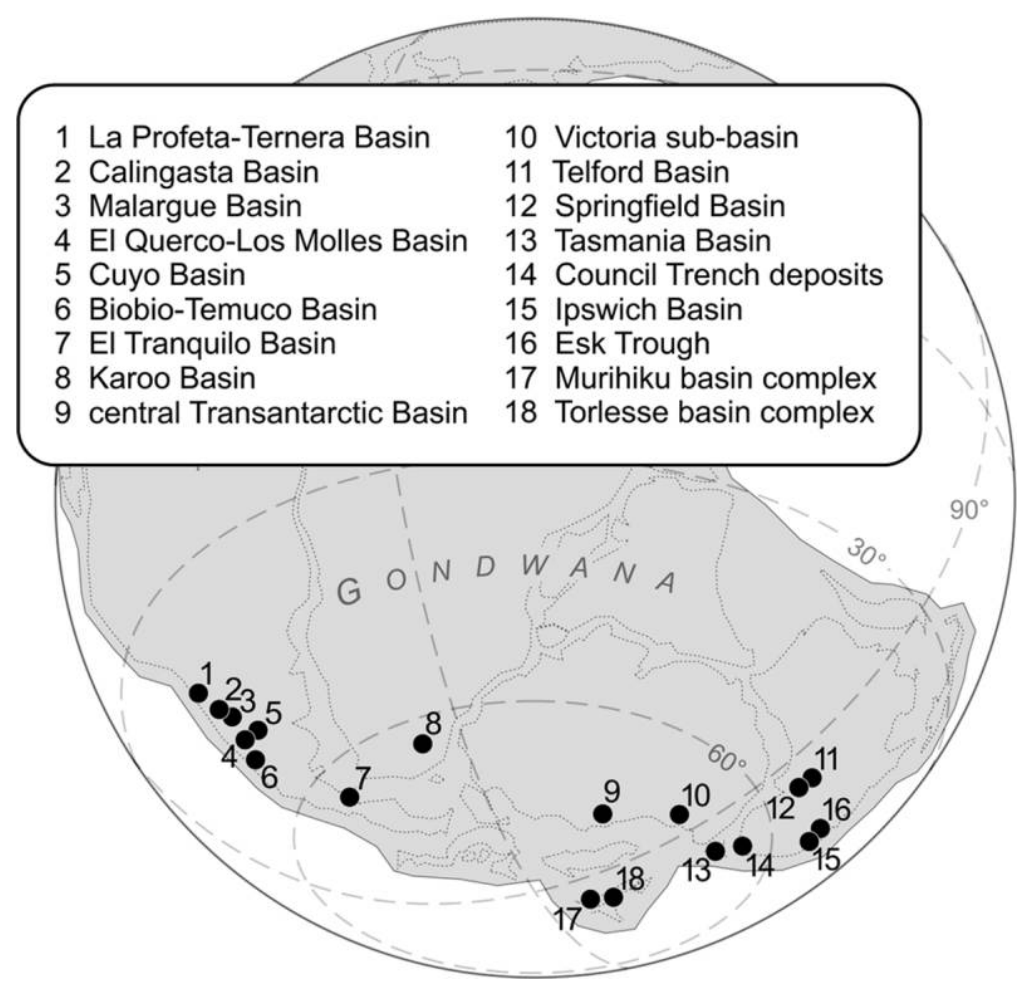

Fig. 6 Paleogeographic occurrences of petriellalean fossils. Base map for the Late Triassic after Lawver et al. (1998); fossil occurrences compiled from Anderson and Anderson (2003), Barone-Nugent et al. (2003), Holmes and Anderson (2005), Artabe et al. (2007), Morel et al. (2011), and this study.

et al. 2011, 2013a; Escapa et al. 2011). Furthermore, petriellalean compression fossils are overall notably rare, occurring in only 2 of 49 or more plant-fossil assemblages surveyed. They are absent in the typical "leaf-litter assemblages"-which accumulated during quiescent conditions through the physiological loss of leaves and reproductive organs of seasonally deciduous gymnosperm trees (table 1; Bomfleur et al. 2011, 2013a)—and are preserved only in rather unusual plant-fossil assemblages; plant level 2 from the Allan Hills, for example, contains redeposited, complete fern rhizomes with attached fronds and croziers (T. N. Taylor et al. 1990; Phipps et al. 1998), subterranean organs of sphenophytes (Bomfleur et al. 2013b), and abundant debris of leafy and thallose bryophytes (Bomfleur et al. 2014a). At the Alfie's Elbow site, petriellalean remains occur only in the level 2 bed, which also yielded (1) the only known occurrence of corystosperm reproductive organs attached to short shoots (Taylor et al. 1998; Axsmith et al. 2000, 2007), (2) one of only three known occurrences worldwide of attached $D i$ croidium leaves (Axsmith et al. 2000), and (3) the only known record of dipterid ferns in the Antarctic Triassic (Escapa et al. 2011). We interpret this rich assortment of otherwise rare plant taxa and organs and the extraordinary proportion of attached organs to reflect high-energy depositional events (e.g., catastrophic river flooding or riverbank collapse after heavy rainstorms) that caused traumatic removal of living plants and plant parts, especially cryptogamic ground cover
(Bomfleur et al. 2014a). Of further significance is the unusual preservation mode of petriellalean plants in the Nymboida Coal Measures of Australia, where they are commonly preserved in the form of a succession of pseudowhorls of complete, attached leaves that spread from an upright-buried stem (Holmes and Anderson 2005, figs. 18-20)-a distinctive form of in situ burial that is uncommon among gymnosperms (but see Anderson and Holmes 2008) and much more typical of sphenophytes (see, e.g., Oplustil et al. 2007, fig. 2; Libertín et al. 2009, pl. VI, 3, fig. 10; Thomas 2014, fig. 13).

Altogether, the complement of morphological, anatomical, and taphonomic evidence demonstrates that the Petriellales were low-growing, shade-adapted, perennial evergreens. The vast number and small size of their seeds-borne in dehiscent seedpods-is typical of pioneers and colonizers that litter large quantities of seeds through ballistic dispersal (Howe and Smallwood 1982).

\section{Ecology and Paleoenvironment}

This reconstruction gains particular significance in light of the unusual paleogeographic and paleoenvironmental setting of the Antarctic Petriellales in the Triassic polar forest biome of Gondwana (fig. 6). Canopy and subcanopy trees in these forests are composed of a diverse array of seed plants dominated by corystosperm seed ferns and voltzialean conifers (fig. 7). Studies of anatomically preserved material in the 


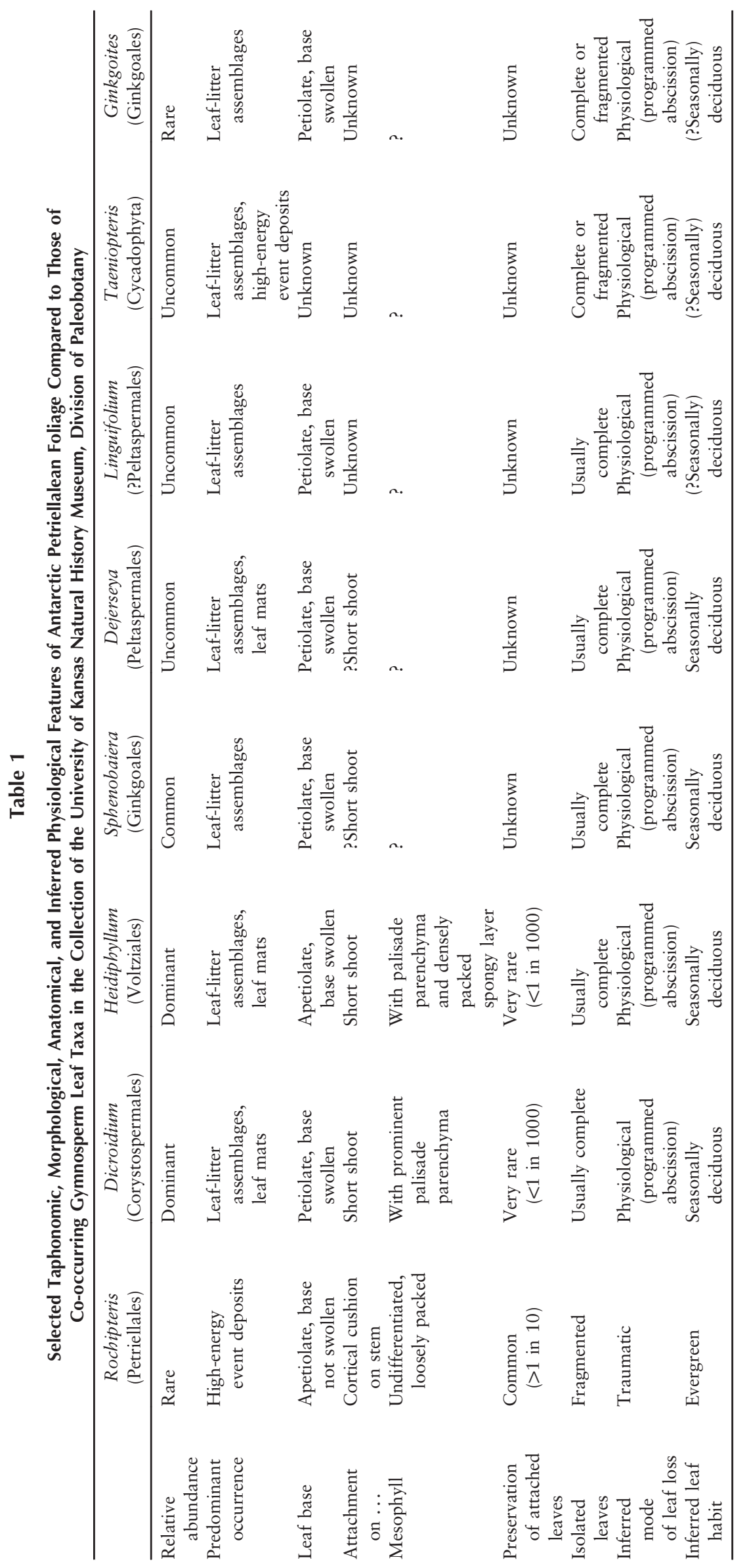

This content downloaded from 168.096.240.002 on June 26, 2017 08:17:22 AM 


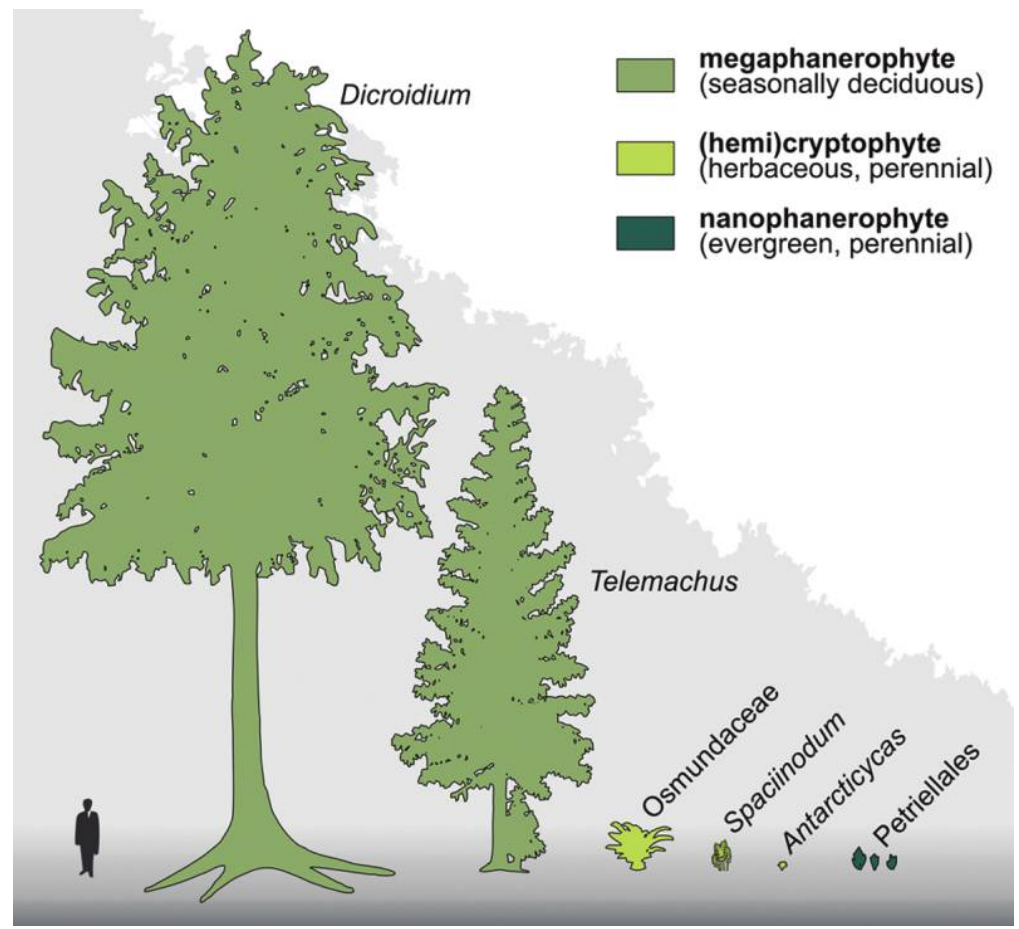

Fig. 7 Comparison of morphology and inferred life mode (Raunkiær classification) of selected well-known plants from the Triassic polar forest biome of present-day Antarctica.

Triassic silicified peat deposits have enabled very detailed reconstructions of these plants (e.g., Taylor and Taylor 1990; Hermsen et al. 2009; Bomfleur et al. 2013a; see Escapa et al. 2011; Cantrill and Poole 2012). Other gymnosperm groups are more or less well documented by leaf compressions, including Dejerseya and Lepidopteris (Peltaspermales), Sphenobaiera and Ginkgoites (Ginkgoales), Taeniopteris (cycadophytes), and Rissikia (Podocarpaceae; Bomfleur et al. 2011; Escapa et al. 2011; Cantrill and Poole 2012). Although anatomical details are not yet known for these plants, all are considered to represent seasonally deciduous trees or tall shrubs, based on their usual preservation in the form of accumulations of abscised, complete leaves (Bomfleur et al. 2011, 2013a; Escapa et al. 2011) or foliar spurs (Rissikia; Townrow 1967). A peculiar exception is Antarcticycas, a diminutive cycad whose small $(<10$-cm-tall $)$ stem was probably subterranean (Hermsen et al. 2009). Whether its leaves were actively shed or shriveled on the plant remains uncertain; it is noteworthy, however, that none of the several dozens of stems found so far bears attached leaves, although the stems are commonly covered in cataphylls (R. Serbet, personal communication, 2013) and seem to be preserved in situ in the peat matrix, together indicating a probable deciduous habit.

The most common understory plants in the Triassic polar forests of Antarctica were apparently osmundaceous ferns, judging from the widespread occurrences of their foliage (Cladophlebis, "fossil Osmunda") and rhizomes (Ashicaulis; T. N. Taylor et al. 1990; Escapa et al. 2011; Cantrill and
Poole 2012). By analogy with their very similar extant relatives (Phipps et al. 1998; Rothwell et al. 2002; Bomfleur et al. $2014 b$ ), there is good evidence to suggest that the Triassic Osmundaceae were herbaceous perennials. Other fern groups are much rarer in the Triassic of Antarctica and belong to Marattiaceae, Matoniaceae, Gleicheniaceae, and Dipteridaceae (Escapa et al. 2011; Cantrill and Poole 2012). Extant representatives of these fern families are evergreen terrestrial plants in (sub)tropical regions. At present, it is impossible to ascertain whether the Triassic high-latitude representatives of these groups were herbaceous perennials similar to the cooccurring Osmundaceae-as the prevalent strongly seasonal climate might suggest. The Equisetum-like sphenophyte Spaciinodum was also a common herbaceous perennial in the Triassic polar vegetation, producing seasonal dormant buds to endure winter (Ryberg et al. 2008).

By and large, at the end of each growth season, the entire forest canopy must have shed its leaves and-together with the herbaceous understory plants-entered dormancy to endure the prolonged period of winter darkness. The Petriellales apparently established a very different mode of life in this environment: they formed low-growing understory vegetation that colonized the forest floor and remained evergreen during winter, immersed alone in the dark for up to several months in a quiescent forest (figs. 7,8 ). Some understory plants in deciduous forests today are known to assimilate the highest carbon amounts over an entire year during the short periods of increased exposure before canopy closure in early spring and after canopy fall in late autumn (Fridley 2012). 


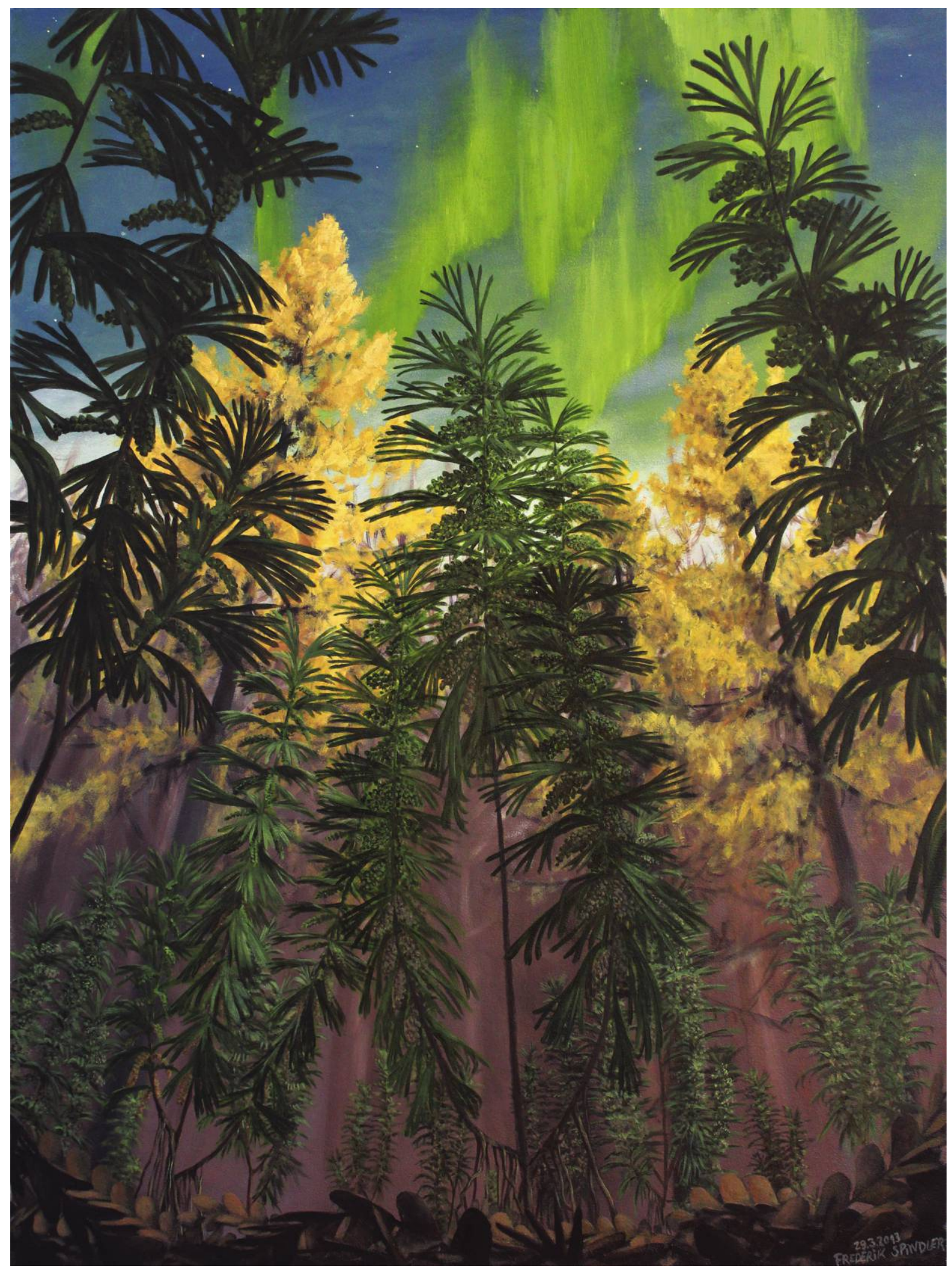

Fig. 8 Suggested reconstruction of a group of small evergreen petriellalean plants on the floor of a polar forest of Dicroidium and Telemachus trees at the onset of winter, some $230 \mathrm{Myr}$ ago in what is now East Antarctica. Artwork by F. Spindler (Freiberg, Germany; http:// www.frederik-spindler.de). 
In the warm polar forests of the Triassic, then, the evergreen habit and the prominent adaptations to low-light photosynthesis can be expected to have extended the effective growing season of the Petriellales significantly beyond that of the deciduous canopy trees, enabling these plants to exploit the autumn niche (see Fridley 2012) and, perhaps, to continue assimilation even during the transitional phases of prolonged twilight.

Many authors have noted the similarity of petriellalean cupules to those of the Caytoniales, a group of gymnosperms that continues to figure prominently in theories about the mysterious origin of flowering plants (e.g., Thomas 1925; Crane 1985; Doyle 2006; Taylor and Taylor 2009). Recent hypotheses propose that the earliest angiosperms may have been small, woody shrubs that colonized disturbed sites in the damp understory of humid forests (Feild et al. 2004; Feild and Arens 2005, 2007; see Coiffard et al. 2012). The reconstructed physiology and ecology of the Petriellales matches this life form to such detail that we suggest these unusual gymnosperms may represent convergent ecological analogues of early flowering plants.

Our knowledge of the Petriellales is still incomplete, as our search for anatomically preserved pollen organs and rooting structures has so far been unfruitful. However, the already comprehensive information about their morphology, anatomy, and physiology places the Petriellales at once among the most completely reconstructed groups of extinct gymnosperms. We anticipate that the evident question-whether beyond the mere ecological similarity there may be phylogenetic relationships linking Petriellales to angiosperms-will be answered once more detailed information about their reproductive biology becomes available.

\section{Acknowledgments}

We thank H. M. Anderson (Johannesburg), Mike Dunn (Lawton, OK), and R. Spicer (Milton Keynes) for helpful discussion; R. Serbet (Lawrence, KS) for technical assistance and discussion; F. Spindler (Freiberg, Germany) for the reconstruction drawing; and six anonymous reviewers for comments on early versions of the manuscript. Financial support was provided by the Alexander von Humboldt-Stiftung (Feodor Lynen fellowship to B. Bomfleur), the Agencia Nacional de Promoción Científica y Tecnológica (PICT-20102322 to I. H. Escapa), the National Science Foundation (ANT0943934 to E. L. Taylor and T. N. Taylor), and the Swedish Research Council (VR grant to S. McLoughlin). AMAP (Botany and Computational Plant Architecture; http://amap.cirad .fr) is a joint research unit with associates CIRAD (UMR51), CNRS (UMR5120), INRA (UMR931), IRD (R123), and Montpellier 2 University (UM2).

\section{Literature Cited}

Anderson HM, WBK Holmes 2008 Stems with attached Dicroidium leaves from the Ipswich Coal Measures, Queensland, Australia. Mem Qld Mus 52:1-12.

Anderson JM, HM Anderson 2003 Heyday of the gymnosperms: systematics and biodiversity of the Late Triassic Molteno fructifications. National Botanical Institute, Pretoria.

Artabe AE, EM Morel, DG Ganuza, AM Zavattieri, LA Spalletti 2007 La paleoflora triásica de Potrerillos, provinica de Mendoza, Argentina. Ameghiniana 44:279-301.

Askin RA, TJ Cully 1998 Permian to Jurassic palynological collections in the Shackleton Glacier area. Antarct J US 31:3-5.

Axsmith BJ, EL Taylor, TN Taylor 2007 The "new approach to Corystospermales" and the Antarctic fossil record: a critique. Ameghiniana 44:223-230.

Axsmith BJ, EL Taylor, TN Taylor, NR Cuneo 2000 New perspectives on the Mesozoic seed fern order Corystospermales based on attached organs from the Triassic of Antarctica. Am I Bot 87:757-768.

Axsmith BJ, TN Taylor, EL Taylor 1998 Anatomically preserved leaves of the conifer Notophytum krauselii (Podocarpaceae) from the Triassic of Antarctica. Am I Bot 85:704-713.

Barone-Nugent ED, S McLoughlin, AN Drinnan 2003 New species of Rochipteris from the Upper Triassic of Australia. Rev Palaeobot Palvnol 123:273-287.

Bomfleur B, A-L Decombeix, IH Escapa, AB Schwendemann, B Axsmith 2013a Whole-plant concept and environment reconstruction of a Telemachus conifer (Voltziales) from the Triassic of Antarctica. Int I Plant Sci 174:425-444.

Bomfleur B, IH Escapa, EL Taylor, TN Taylor 2013b A reappraisal of Neocalamites and Schizoneura (fossil Equisetales) based on material from the Triassic of East Antarctica. Alcheringa 37:1-17.

Bomfleur B, H Kerp 2010 Dicroidium diversity in the Upper Triassic of north Victoria Land, East Antarctica. Rev Palaeobot Palvnol 160:67-101.
Bomfleur B, AA Klymiuk, EL Taylor, TN Taylor, EL Gulbranson, JL Isbell 2014a Diverse bryophyte mesofossils from the Triassic of Antarctica. Lethaia 47:120-132.

Bomfleur B, S McLoughlin, V Vajda $2014 b$ Fossilized nuclei and chromosomes reveal 180 million years of genomic stasis in royal ferns. Science 343:1376-1377.

Bomfleur B, EL Taylor, TN Taylor, R Serbet, M Krings, H Kerp 2011 Systematics and paleoecology of a new peltaspermalean seed fern from the Triassic polar vegetation of Gondwana. Int I Plant Sci 172:807-835.

Boucher LD, EL Taylor, TN Taylor, NR Cúneo, JM Osborn 1995 Dicroidium compression floras from southern Victoria Land. Antarct J US 30:40-41.

Cantrill DJ, I Poole 2012 The vegetation of Antarctica through geological time. Cambridge University Press, Cambridge.

Coiffard C, B Gomez, V Daviero-Gomez, DL Dilcher 2012 Rise to dominance of angiosperm pioneers in European Cretaceous environments. Proc Natl Acad Sci USA 109:20955-20959.

Crane PR 1985 Phylogenetic analysis of seed plants and the origin of angiosperms. Ann Mo Bot Gard 72:716-793.

Doyle JA 2006 Seed ferns and the origin of angiosperms. L Torrev Bot Soc 133:169-209.

2008 Integrating molecular phylogenetic and paleobotanical evidence on origin of the flower. Int I Plant Sci 169:816-843.

Escapa IH, EL Taylor, R Cuneo, B Bomfleur, J Bergene, R Serbet, TN Taylor 2011 Triassic floras of Antarctica: plant diversity and distribution in high paleolatitude communities. Palaios 26:522-544.

Farabee MJ, EL Taylor, TN Taylor 1990 Correlation of Permian and Triassic palynomorph assemblages from the central Transantarctic Mountains, Antarctica. Rev Palaeobot Palvnol 65:257265.

Fasola A 1974 Palynological study of Triassic samples from the Beardmore Glacier area in Antarctica. MSc thesis. Ohio State University, Athens. 
Feild TS, NC Arens 2005 Form, function, and environments of the early angiosperms: merging extant phylogeny and ecophysiology with fossils. New Phytol 166:383-408.

2007 The ecophysiology of early angiosperms. Plant Cell Environ 30:291-309.

Feild TS, NC Arens, JA Doyle, TE Dawson, MJ Donoghue 2004 Dark and disturbed: a new image of early angiosperm ecology. Paleobiology 30:82-107.

Fridley JD 2012 Extended leaf phenology and the autumn niche in deciduous forest invasions. Nature 485:359-362.

Frohlich MW 2003 An evolutionary scenario for the origin of flowers. Nat Rev Genet 4:559-566.

Frohlich MW, MW Chase 2007 After a dozen years of progress the origin of angiosperms is still a great mystery. Nature 450:11841189.

Gabites HI 1985 Triassic paleoecology of the Lashly Formation, Transantarctic Mts., Antarctica. MSc thesis. Victoria University, Wellington, New Zealand.

Galtier J, TL Phillips 1999 The acetate peel technique. Pages 67-70 in TP Jones, NP Rowe, eds. Fossil plants and spores: modern techniques. Geological Society, London.

Givnish TJ 1988 Adaptation to sun and shade: a whole-plant perspective. Aust I Plant Physiol 15:63-92.

2002 Adaptive significance of evergreen vs. deciduous leaves: solving the triple paradox. Silva Fenn 36:703-743.

Helby R, R Morgan, AD Partridge 1987 A palynological zonation of the Australian Mesozoic. Mem Assoc Austral Palaeontol 4:1-94.

Herbst R, A Troncoso, S Gnaedinger 2001 Rochipteris nov. gen., hojas incertae sedis (= Chiropteris pro parte) del Triásico Superior de Argentina y Chile. Ameghiniana 38:257-269.

Hermsen EJ, EL Taylor, TN Taylor 2009 Morphology and ecology of the Antarcticycas plant. Rev Palaeobot Palynol 153:108-123.

Holmes WBK, HM Anderson 2005 The Middle Triassic megafossil flora of the Basin Creek Formation, Nymboida Coal Measures, New South Wales, Australia. 5. The genera Lepidopteris, Kurtziana, Rochipteris and Walkomiopteris. Proc Linn Soc NSW 126: 39.

Howe HF, J Smallwood 1982 Ecology of seed dispersal. Annu Rev Ecol Syst 13:201-228.

Kyle RA 1977 Palynostratigraphy of the Victoria Group of South Victoria Land, Antarctica. NZ I Geol Geophys 20:1081-1102.

Kyle RA, JM Schopf 1982 Permian and Triassic palynostratigraphy of the Victoria Group, Transantarctic Mountains. Pages 649-659 in $\mathrm{C}$ Craddock, ed. Antarctic geoscience. University of Wisconsin Press, Madison.

Lawver LA, LM Gahagan, IWD Dalziel 1998 A tight fit: early Mesozoic Gondwana, a plate reconstruction perspective. Pages 214229 in Y Motoyoshi, K Shiraishi, eds. Proceedings of the international symposium "Origin and Evolution of Continents." Memoirs of the National Institute of Polar Research, Special Issue 53.

Libertín M, S Oplustil, J Psenicka, J Bek, I Sykorová, J Dasková 2009 Middle Pennsylvanian pioneer plant assemblage buried in situ by volcanic ash-fall, central Bohemia, Czech Republic. Rev Palaeobot Palynol 155:204-233.

Melville R 1976 The terminology of leaf architecture. Taxon 25:549_ 561.

Meyer-Berthaud B, TN Taylor 1991 A probable conifer with podocarpacean affinities from the Triassic of Antarctica. Rev Palaeobot Palynol 67:179-198.

Meyer-Berthaud B, TN Taylor, EL Taylor 1993 Petrified stems bearing Dicroidium leaves from the Triassic of Antarctica. Palaeontology 36:337-356.

Morel EM, AE Artabe, DG Ganuza, A Zúñiga 2011 La paleoflora triásica del Cerro Cacheuta, Provincia de Mendoza, Argentina.
Petriellales, Cycadales, Ginkgoales, Voltziales, Coniferales, Gnetales y gimnospermas incertae sedis. Ameghiniana 48:520-540.

Niklas KJ 1993 The scaling of plant height: a comparison among major plant clades and anatomical grades. Ann Bot 72:165-172.

Oplustil S, J Psenicka, M Libertín, Z Simunek 2007 Vegetation patterns of Westphalian and Lower Stephanian mire assemblages preserved in tuff beds of the continental basins of Czech Republic. Rev Palaeobot Palvnol 143:107-154.

Phipps CJ, TN Taylor, EL Taylor, NR Cuneo, LD Boucher, X Yao 1998 Osmunda (Osmundaceae) from the Triassic of Antarctica: an example of evolutionary stasis. Am I Bot 85:888-895.

Pigg KB 1990 Anatomically preserved Dicroidium foliage from the central Transantarctic Mountains. Rev Palaeobot Palynol 66:129_ 145.

Rothwell GW, EL Taylor, TN Taylor 2002 Ashicaulis woolfei n. sp.: additional evidence for the antiquity of osmundaceous ferns from the Triassic of Antarctica. Am I Bot 89:352-361.

Ryberg PE, EJ Hermsen, EL Taylor, TN Taylor, JM Osborn 2008 Development and ecological implications of dormant buds in the high-paleolatitude Triassic sphenophyte Spaciinodum (Equisetaceae). Am I Bot 95:1443-1453.

Seward AC 1914 Antarctic fossil plants. British Antarctic ("Terra Nova”) expedition, 1910. British Museum Natural History Report. Geology 1:1-49.

Smith WK, TC Vogelmann, EH DeLucia, DT Bell, KA Shepherd 1997 Leaf form and photosynthesis. BioScience 47:785-793.

Spicer RA, JL Chapman 1990 Climate change and the evolution of high-latitude terrestrial vegetation and floras. Trends Ecol Evol 5:279-284.

Taylor EL, PE Ryberg 2007 Tree growth at polar latitudes based on fossil tree ring analysis. Palaeogeogr Palaeoclimatol Palaeoecol 255:246-264.

Taylor EL, TN Taylor 1993 Fossil tree rings and paleoclimate from the Triassic of Antarctica. Pages 453-455 in SG Lucas, M Morales, eds. The nonmarine Triassic. New Mexico Museum of Natural History Science Bulletin 3.

2009 Seed ferns from the late Paleozoic and Mesozoic: any angiosperm ancestors lurking there? Am I Bot 96:237-251.

Taylor EL, TN Taylor, NR Cúneo, A Archangelsky, H Kerp 1998 Seed fern reproductive organs from the Shackleton Glacier area. Antarct J US 31:27-29.

Taylor EL, TN Taylor, B Meyer-Berthaud, JL Isbell, NR Cúneo 1990 A Late Triassic flora from the Allan Hills, southern Victoria Land. Antarct J US 25:20-21.

Taylor TN, GM del Fueyo, EL Taylor 1994 Permineralized seed fern cupules from the Triassic of Antarctica: implications for cupule and carpel evolution. Am I Bot 81:666-677.

Taylor TN, EL Taylor 1987 An unusual gymnospermous reproductive structure of Triassic age. Antarct J US 22:29-30.

1990 Antarctic paleobiology: its role in the reconstruction of Gondwana. Springer, New York.

Taylor TN, EL Taylor, B Meyer-Berthaud, JL Isbell, NR Cúneo 1990 Triassic osmundaceous ferns from the Allan Hills, southern Victoria Land. Antarct J US 25:18-19.

Thomas BA 2014 In situ stems: preservation states and growth habits of the Pennsylvanian (Carboniferous) calamitaleans based upon new studies of Calamites Sternberg, 1820 in the Duckmantian at Brymbo, North Wales, UK. Palaeontology 57:21-36.

Thomas HH 1925 The Caytoniales, a new group of angiospermous plants from the Jurassic rocks of Yorkshire. Philos Trans R Soc B 213:299-363.

Townrow JA 1967 On Rissikia and Mataia podocarpaceous conifers from the lower Mesozoic of southern lands. Pap Proc R Soc Tasman 101:103-136. 